w Poznaniu

dgapska@amu.edu.pl

\title{
Żywot królowej Jeleny Danila II jako wzór idealnej symfonii państwa z Kościołem
}

\begin{abstract}
Gapska Dominika, Żywot królowej Jeleny Danila II jako wzór idealnej symfonii państwa z Kościołem (Life of Queen Helen by Daniel II as a Model of Perfect Symphony of the State and the Church). "Poznańskie Studia Slawistyczne" 10. Poznań 2016. Publishing House of the Poznań Society for the Advancement of the Arts and Sciences, pp. 99-113. ISSN 2084-3011.

The aim of this article is to describe and analyze relations between Serbian medieval queen Helen of Anjou and the Serbian Orthodox Church presented in a literary vision of her life written by archbishop Daniel II. The text of Helen's life shows them as a model of perfect symphony of sacerdotium and imperium. She fulfils St. Sava political ideology and is famous in Serbia because of her generous patronage over the Church, charity deeds and active political life. Despite being Roman Catholic by birth she was cannonized as a Orthodox saint and she kept friendly relations with the Orthodox Church spiritual authorities.
\end{abstract}

KeYwords: Serbian Saint; Serbian Orthodox Church; Serbian Holy women; St. Helen of Anjou

Postać Jeleny Andegaweńskiej (ok. 1236-1314, fr. Hélène d’Anjou, serb. Jelena Anžujska, mniszka Jelisaveta) jest w serbskiej historii Kościoła szczególna. To jedyna święta, która będąc przez większość życia katoliczką („łacinniczką") ${ }^{1}$ została otoczona kultem przez Cerkiew prawosławną, nie tylko w Serbii, ale także w Rosji i Polsce. Była jedną z pierwszych narodowych świętych i jako jedna z niewielu kobiet na serbskich ołtarzach miała oficjalną ceremonię potwierdzającą świętość - stało się to na soborze w 1317 roku. Ma swój dzień pamięci w kalendarzu liturgicznym (30 października); w monasterze Gradac wspomina się królową także w każdą rocznicę jej śmierci -8 lutego.

${ }^{1}$ Hipotezę, że Jelena nie przeszła na prawosławie stawiają np. Васић 1926: 240-355; Злоковић 1936: 75-77; Ћирковић 1981: 347-348. 
Pochodzenie Jeleny było przedmiotem zainteresowania wielu badaczy (nр. Јиречек 1952; Мијатовић 1902). Pierwotnie sądzono, że była ona bezpośrednio spokrewniona z królem Francji, Ludwikiem IX, Karolem I Andegaweńskim, królem Neapolu (Мијатовић 1902: 10-11) lub z rodem de Courtenay, co nie znalazło potwierdzenia w źródłach historycznych i do dziś pozostaje spekulacją. Nową, najbardziej prawdopodobną, bo odpowiadającą trzynastowiecznym serbskim realiom i silnie popartą dokumentami, teorię rodowodu Jeleny wysunął Gordon L. McDaniel. Jego zdaniem była najstarszą córką węgierskiego szlachcica greckiego pochodzenia Jana Angelosa $^{2}$, zarządcy Sremu i hrabiego Kovin (domino Sirmy et comite de Kewe) oraz Francuzki Matyldy z Požegi (Matildis dominae de Posaga) (McDaniel 1982-1983: 43-44). Około roku 1250 Jelena została wydana za mąż za serbskiego króla Stefana Uroša I (1243-1276), z którym miała dwóch synów: Stefana Dragutina (1276-1282) i Stefana Uroša II Milutina (1282-1321). Po objęciu władzy przez Dragutina Jelena otrzymała od niego tereny między Zetą a Skadrem, którymi władała do śmierci 8 lutego 1314 roku.

Królowa zapisała się w historii głównie jako opiekunka Kościołów prawosławnego i rzymskokatolickiego w Serbii. Według badaczy szczególna aktywność fundacyjna Jeleny przypada na ostatnie dziesięciolecia XIII wieku. Narasta wokół tego faktu wiele wątpliwości, ponieważ dokumenty źródłowe nie zawsze bezpośrednio wymieniają królową z imienia, a zdarza się, że kronikarze mylą ją z siostrą - Marią de Chau (Суботић 1958: 139-140).

O franciszkańskich fundacjach Jeleny na terenie Zety w zasadzie wspomina tylko Danielis Farlati (1690-1773), włoski jezuita i historyk chrześcijaństwa (Illyricum sacrum). Według niego wśród zeckich zadužbin Jeleny miał znajdować się franciszkański klasztor z 1288 roku w Barze (Farlati 1813: 13). Władczyni darowała mu jakoby też wyposażenie i utensylia liturgiczne (wszystkie „rzeczy niezbędne”) (Farlati 1813: 44). Farlati wspomina, że w tym samym roku, czyli 1288, Jelena przyczyniła się do

${ }^{2}$ Jan był synem bizantyńskiego cesarza Izaaka II Komnena (1156-1204) i węgierskiej księżniczki Małgorzaty (1175-1223), córki Beli III Arpada (1148-1196), szykowanego do objęcia cesarskiego tronu Bizancjum, lecz plany te nie doszły do skutku. V. Salamon 2002: 74. 
powstania trzech wspólnot mniszych - w Skadrze (Marii Panny), Ulcinju (Marii Panny) i Kotorze (św. Franciszka) (1813: 59, 309 i 252).

Większość wspieranych przez nią kościołów i klasztorów na zeckim Primorju była rzymskokatolicka (Суботић 1958: 147). Wyjątek to prawosławna cerkiew św. Mikołaja na Vranjini (dziś Czarnogóra), którą królowa wsparła darami i potwierdziła nadania własności ziemskich. Jeszcze w latach pięćdziesiątych XX wieku kwestionowano autentyczność chryzobulli królowej, przepisanej przez mnicha Gavrila, w której potwierdza ona wcześniejszy majątek wspólnoty i przesyła nowe dary (Суботић 1958: 137-138). Dopiero badania Božidara Šekularaca dowiodły autentyczności bulli i poparły wcześniejsze przypuszczenia, że królowa Jelena sprzyjała także prawosławnym instytucjom na terenie Zety i Primorja (Шекуларац 1984: 39-43, 146). Miroslav Popović w swoich pracach podkreśla, że finansowym patronatem królowej objęty był cały Kościół, niezależnie od denominacji. W nadmorskich miastach powstawały świątynie obrządku rzymskiego, w głębi kraju królowa hojnie wspierała Cerkiew prawosławną (Поповић 2010: 64; Суботић 1958: 147).

Jako władczyni Jelena prowadziła aktywne życie polityczne, niekiedy w opozycji do działań męża, np. otwarcie oferowała Dubrownikowi swoją pomoc w trakcie konfliktu z Urošem w latach 1255-1256, z powodu której została nawet posądzona o zdradę (Ћоровић 1997). Samodzielnie kształtowała też politykę religijną, dziś powiedzielibyśmy w duchu ekumenicznym, ponieważ utrzymywała równie dobre kontakty z duchowieństwem prawosławnym i katolickim. Przez wiele lat oficjalnie wspierała katolickie biskupstwo w Barze i przyczyniła się do chirotonii biskupiej swego bliskiego współpracownika, archidiakona Mar(t)ina (Поповић 2010: 76). Wiadomo także, że miała żywe kontakty z papiestwem, szczególnie z Mikołajem IV (1277-1292), który działał na rzecz unifikacji obu Kościołów. W liście z 6 sierpnia 1288 roku papież chwalił pobożność królowej i jej wsparcie dla kościołów rzymskokatolickich na terenach, którymi władała. Prosił także, by przyjęła na dworze wysłanników kurii (Поповић 2010: 82-83). Bezpośredniość tej prośby skłania do przypuszczeń, że królowa mogła sprzyjać promowanym przez niego ideom zjednoczeniowym.

Wśród bliskich doradców Jeleny było również duchowieństwo Cerkwi prawosławnej. Między nimi szczególne miejsce zajmowali Danilo II (ok. 1270-1337, arcybiskup serbski 1324-1337) i biskup Raški Pavle (?) - na 
życzenie królowej obaj czuwali przy jej łożu śmierci. Spośród duchownych źródła wspominają także arcybiskupa Joanikija I (?-1279; arcybiskup w latach 1272-1276), Jovana, biskupa Humu (1306-1316) i Dujama (Domnius I), katolickiego biskupa kotorskiego (1280-1326). Charakter tych związków jest słabo udokumentowany, według badaczy „wysoko ich ceniła” i „otaczała należnym szacunkiem” (Поповић 2010: 78).

W trzy lata po śmierci królowej zapadła decyzja o wyniesieniu jej na ołtarze przez serbską Cerkiew. Uroczystość kanonizacyjna odbyła się przy udziale najwyższych przedstawicieli serbskiego duchowieństwa - w tym arcybiskupa Sawy III (1309-1316), biskupów Danila II i Pavle. Dziś to posunięcie jest uważane za element szerszego programu religijno-politycznego dynastii Nemanjiciów, opracowanego w celu ujednolicenia religijnego kraju, gloryfikacji państwa, pochwały narodu i usankcjonowania jego wybraństwa (Gil 2005: 58-60). Bardzo możliwe także, że Danilo II forsował proces kanonizacyjny Jeleny, by złagodzić nastroje panujące po soborze w Lyonie (1274) (Gil 2005: 60) i ubiec pretensje ze strony Kościoła katolickiego, dotyczące fundacji w Gradacu oraz obszaru, który władczyni jeszcze w 1303 roku poleciła opiece Rzymu (Павловић 1965: 258).

Najbardziej znanym serbskim utworem poświęconym królowej jest żywot ze zbioru Danila II Životi kraljeva $i$ arhiepiskopa srpskih z pierwszej połowy XIV wieku. Z osobą tego autora należy łączyć ustanowienie i rozwój kultu Jeleny, rozpowszechnionego przez hagiografię także w innych Kościołach prawosławnych. Danilo napisał żywot zgodnie z duchowością monastyczną; obraz królowej został w nim wyidealizowany. Autor podaje niewiele faktów historycznych - długie i zajmujące rządy królowej sprowadzają się do kilku ogólnych stwierdzeń, np. że wraz z mężem wiodła „chwalebne i piękne życie”, a po jego śmierci otrzymała od syna część państwa we władanie („достојни део државе земаља многих” - Данило II 1988: $82^{3}$ ). Nie ma także pogłębionej charakterystyki postaci. Na plan pierwszy wybija się figura świętej królowej mniszki, której ziemska władza, w myśl idei teokratycznej, podporządkowana jest realizacji nadrzędnej woli Boskiej i która dąży do urzeczywistnienia uniwersalnych zasad ustanowionych przez Boga. Danilo, odrzucając fakty historyczne z życia

\footnotetext{
${ }^{3}$ Korzystam z serbskiego przekładu żywota, by udostępnić tekst szerszemu gronu odbiorców.
} 
Jeleny, kreuje obraz władczyni (oraz państwa), który będzie odpowiadał potrzebom polityki dynastycznej Nemanjiciów i realizował doktrynę diarchii, wyobrażającą państwo i Kościół ,jako równie zależne od Boga - jedynego suwerena, dominusa, władcy (pantokrator, svedržitelj) wszystkiego co istnieje, uosobienia władzy absolutnej rozumianej soteriologicznie" (Gil 2005: 66).

Z perspektywy Danila w Serbii pod berłem Jeleny imperium całkowicie przenika się z sacerdotium. Teksty euchograficzne (modlitwy) i epistolograficzne - jakie miała królowa wymieniać ze swoimi przewodnikami duchowymi - służą autorowi do bezpośredniego zaprezentowania pola działania każdej ze sfer. Cytat z korespondencji pozwala mu ustami władczyni przedstawić funkcje duchowieństwa (Kościoła), a ustami kleru obowiązki króla (państwa). Chwyt ten umożliwia jednocześnie wskazanie źródła jakiegoś uprawnienia lub zadania oraz wyrażenie aprobaty dla ustalonych reguł. Przywilejów w żywocie Danilo nie zamieszcza, ponieważ ziemską misję państwa i Kościoła wpisuje w obraz powołania do trudnej służby Bogu, według teologii kazania na górze Jezusa (Mt $5^{4}$ ), a przede wszystkim moralności ,wąskiej drogi” (Mt 7,13-14).

Klucz interpretacyjny tekstu i wizerunku Jeleny znajduje się we wstępie, gdzie autor głosi pochwałę suwerenności Boga - Stworzyciela świata, źródła ziemskiego porządku i jedynego sędziego człowieka. Opiera go na intronizacyjnym psalmie drugim (w. 10-12) o prawdziwym udziale Stwórcy w rządach nad światem i konieczności służenia mu z „bojaźnią” przez ziemskich włodarzy (Ps 2,11) jako Bożych pomazańców pod groźbą słusznego gniewu Pana. Sprawowanie władzy uważa się za życiową próbę, dzięki której można osiągnąć niebo lub - w razie niepowodzenia - zostać skazanym na piekło. Za kryterium oceny służy podejście do otrzymywanego wraz z władzą bogactwa, jakim jest wspaniałe serbskie państwo, oraz do poddanych - ludzi słabszych, pozbawionych dostępu do dóbr - intelektualnych (wiedza) i materialnych (dostatek) - ponieważ te znajdują się w gestii panującego.

$\dot{Z} y$ wot Jeleny w opracowaniu Danila II ma cechy autonomicznego, tzn. niezależnego od świętości męża lub/i syna ${ }^{5}$, kultu królowej. Hagiograf

${ }^{4}$ Identyfikacje biblijne wg: Biblia Tysiąclecia, wyd. IV, Poznań 2003.

${ }^{5} \mathrm{~W}$ praktyce liturgicznej jednak kult należy do kultów towarzyszących, zarówno w Serbii, jak i za granicą. Krótki żywot królowej znajduje się w rosyjskim zbiorze hagiograficznym z połowy XIX w. autorstwa arcybiskupa czernihowskiego Filareta (Gumilowskiego), 
dołożył starań, by miała ona wszystkie atrybuty samodzielnego władcy ${ }^{6}$, stworzył jej królewski rodowód, jak wymagała tradycja kulturowa i biblijna (cf. Mt 1,1-17), i zignorował czas rządów za życia męża, „oddając” koronę dopiero po jego śmierci. Pozycja królowej jako Bożego pełnomocnika na ziemi wynika według kreacji Danila z planów Boskiej Opatrzności, zgodnie z którymi już we wczesnej młodości została przeznaczona do spełnienia ważnej misji w życiu (cf. Ef 2,10)ํ.

Јелена била је од племена фрушкога (францускога), кћи славних родитеља, (...). Њу снабде добри и најмилосрднији Бог од њезине младости, унапред знајући све будуће. Ова благочестива (...) би дана од својих родитеља да буде жена великом српском краљу Урошу. Са њиме проводећи живот славно и дивно (Данило II 1988: $81)$.

Chwila przejęcia władzy przez królową odwzorowuje obrzęd postrzyżyn mniszych (pokuta, wyznanie grzechów, śmierć dla ,ś́wiata”), ponieważ ma pokazać transformację bywalczyni ,świata” w świętą monarchinię, sługę Bożą, która wstępuje do Najwyższego Suwerena na służbę, przejmując troskę o kraj i poddanych jako Jego dziedzinę:

и после смрти мужа њезина примивши од вазљубљенога сина свога достојни део државе земаља многих и красних, сетивши се младосних грехова својих и дошавши у велико покајање, умртвљује мисли телесне, и храни свој ум благодаћу божанственога разума, као што је речено у Премудрости Соломоновој: „Ризнице царске испуниће се златом, а умови истинитих подвижника испуниће се богатим разумом” (wg Prz 16,16) (Данило II 1988: 81).

Danilo postrzega serbską władczynię nie tylko jako typowego dla teokracji króla kapłana, ale i króla mnicha, dla którego panowanie stanowi

Святые южных славян, włączony do tekstu dedykowanego królom Milutinowi i Dragutinowi (Филарет 1865). W 1999 roku rosjanka, Tatiana A. Sienina (siostra Kasja), z kręgu alternatywnego prawosławia rosyjskiego napisała nieoficjalne oficjum (służbę) ku czci św. św. Dragutina i Milutina oraz ich matki, v. <http://st-elizabet.narod.ru/>; <http://tsenina. narod.ru/publikasii.htm\#06>, (Naumow 2008). Prawdopodobnie z inicjatywy biskupa Žičy, Chryzostoma (Jovan Stolić, 2003-2012) powstała nowa serbska służba królowej Jelenie, ale, jak dotąd, wykorzystywana jest lokalnie. Tekst ułożony został w środowisku monasteru Gradac, być może przez mniszkę Teodorę, v. <www.novisrbljak.narod.ru/PDF_files/Novi_Srbljak/10-30_Sv_kraljica_Jelena_Anzujska_srb.pdf>, 22.09.2014.

${ }^{6}$ Ideał teokracji nie dopuszcza też obecności dwóch władców w jednym kraju.

${ }^{7}$ Pierwowzór takiego powołania zapisany jest w żywocie Bogurodzicy, której przyjście na świat było elementem Bożej ekonomii zbawienia. 
życiowe „ćwiczenie” (umartwienie) na wzór monastyczny, w związku z czym obłożone jest większymi rygorami - zarówno w stosunku do Boga, jak i do poddanych. Tezę tę potwierdza klasztorno-pustelniczy rodzaj duchowości, jaką autor jej przypisuje ${ }^{8}$, królowa oddaje się postom, stosuje głodówki, ma dar łez, skruchy, pokuty i nawrócenia, nieustannie się modli, całe noce spędza na czuwaniu, kocha „pustynię”, prowadzi mniszy tryb życia („Трпи анђелски живот, свагда умом пустиње гонећи" (Данило II 1988: 84), często uczestniczy w liturgiach, przyjmuje Eucharystię .

Swoją interpretacją Danilo nadał państwu kształt organizacji religijnej, w której życia społeczno-politycznego nie można oddzielić od duchowego. Wizja królowej mniszki nasuwa nawet skojarzenie z zamkniętym państwem-klasztorem, tym bardziej, że dwór Jeleny został „oczyszczony” ze wszystkich świeckich osób, oprócz najbliższej rodziny: męża i synów. Zarazem Danilo umiejętnie związał serbską władczynię i jej państwo z obietnicami mesjańskimi, których nosicielem z założenia jest każda teokracja, budując tekst na kanwie mądrościowych ksiąg biblijnych przypisywanych członkom mesjańskiego rodu Dawida (jemu samemu [Psalmy] lub Salomonowi). Scenę duchowej przemiany Jeleny hagiograf oparł na motcie z Księgi Przysłów, uważanej za dzieło Salomona ${ }^{10}$, o ulotności ziemskich dóbr i prawdziwym słudze ${ }^{11}$ Pańskim. Motto celowo nie zostało przytoczone dokładnie. Dzięki temu odsyła do innych, paralelnych miejsc Pisma Świętego i poszerza semantykę użytych metafor, które tworzą obraz świętego króla - sługi, ucznia, „syna” i dziedzica Bożego na podstawie cnót dobrowolnego ubóstwa (Mt 19,27-30), cierpienia (Mt 16,24), mądrości i duchowego synostwa po uwolnieniu spod władzy ,żywiołów świata” (Ga 4,1-7).

${ }^{8}$ Temat zasługuje na odrębne opracowanie w kontekście rozkwitu duchowości franciszkańskiej w XIII w. (v. Наумов 2013: 430-431).

${ }^{9}$ To rysy klasztornej pobożności, szczególnie regularne praktyki pokutne i liturgiczne (cf. Meyendorff 1984: 249-250).

${ }^{10} \mathrm{~W}$ ten sposób Jelena naśladuje króla Salomona, stając się nowym Salomonem (w innych częściach tekstu nowym Dawidem), a Nemanjicie miejscowym mesjańskim rodem Dawida.

${ }^{11} \mathrm{~W}$ oryginale „podvižnik” (подвижник) - to ktoś więcej niż sługa, to nosiciel heroicznej cnoty cierpienia, który mężnie podejmuje wezwanie Chrystusa do wzięcia krzyża na ramiona i naśladowania Go (Mt 16,24). Nie da się precyzyjnie przełożyć tego terminu na język polski. 
Przyjąwszy stan „królewski” Jelena uznaje Boga za Najwyższego Suwerena i składa Mu pewnego rodzaju przysięgę wierności. Jej relacje z Panem mają za podstawę psalmowe cnoty bojaźni Bożej, posłuszeństwa, pokory, wyrażone w modlitwach: „Зато треба да се прво бојим Твога светога имена и да у свему чиним вољу Твоју, по Богооцу Давиду: «Почетак сваке премудрости је страх Божји (Рs 111(110),10)»» (Данило II 1988: 82).

Boga na ziemi w ujęciu Danila reprezentuje w Serbii Kościół. Stosunki między królową a Kościołem stanowią odbicie układu między nią i Bogiem. W służbie Najwyższemu Suwerenowi władze religijne i świeckie uzupełniają się, ale wobec siebie nie są całkowicie równorzędne, podrzędna bowiem relacja króla do Boga wywyższa Kościół ponad administrację polityczną. W propagowany przez hagiografa ideał osobowy władcy wpisane jest podporządkowanie duchowieństwu w oparciu o te same cnoty bojaźni, posłuszeństwa i pokory, a także głębokiego szacunku, jak w odniesieniu do Boga.

Prawo do prymatu Kościoła hagiograf uzasadnia sakralnym rodowodem stanu kapłańskiego, a dosłownie jego udziałem w imieniu Bożym (za $1 \mathrm{Krl}$ 8,16): „силни у имену Господњем”"2. Usytuowanie między Bożym tronem a człowiekiem nakłada na Kościół odpowiedzialność za sferę duchową w państwie. Oznacza ona nadprzyrodzoną misję wobec świeckiej ludności kraju. Królowa z pokorą sankcjonuje ponadziemską funkcję duchownych, bez których laicy nie mogliby zyskać zbawienia, i oddaje im pod opiekę swoją osobę, tzn. tron. Ta deklaracja, będąca formą przysięgi na wierność Kościołowi, tak jak Bogu, którego jest przedstawicielem, potwierdza nierozerwalny sojusz serbskiego państwa z instytucją religijną:

Господо моја и оци, сетите се да сте ви силни у имену Господњем, и зато сте дужни да носите наше немоћи. Јер ево ми кои смо у сујети овога сујетнога света, ако и хоћемо да духом живимо, (...) то не можемо да постигнемо. (...) Но молите Господа за мене недостојну, не бих ли како богоугодним вашим молитвама постала достојна (...), да доспем у богоугодна места (Данило II 1988: 85-86).

${ }^{12}$ Zamknięte w tych słowach odwołanie biblijne (do aktu poświęcenia świątyni przez Salomona: $1 \mathrm{Krl}$ 8,14-21) rozszerza ich znaczenie o kontekst monarszego błogosławieństwa dla Kościoła oraz ideę przymierza - w tym wypadku między Serbią a Bogiem, który zamieszkał w serbskim Kościele, jak Jahwe w jerozolimskiej świątyni, dopuszczając serbski kler do służby Swojemu ,imieniu”. 
Na mocy pośrednictwa w zbawieniu Kościół obejmuje „tron” (państwo) także misją wychowawczą, nauczycielską i kontrolną. Limituje zakres wolności króla pod rygorem wiecznego potępienia za przekroczenie granic funkcji, skoro władca jako świecki nie ma możliwości stawania we własnej „obronie” przed Bogiem. Zobowiązany do pilnowania ,interesów" Boskiego Suwerena na ziemi, kler dba przede wszystkim o zachowanie istniejącego porządku, wpajając monarchini wzór rządów jako pełnej poświęcenia służby Bożej oraz cnoty, które podtrzymują i umacniają teokratyczny ustrój, czyli posłuszeństwo i bojaźn przed „Królem Królów”:

А ови блажени оци доброразумним речима поучаваху ову (...): „Богољубиво чедо наше, поверено нам у Господу, ево примивши кротке и богоразумне речи твојих писама, насладисмо се. Ако хочеш, можеш земаљским царством искупити небесно (...). Постиди се у садашњем веку онога који те је тако заволео, да се не постидиш у доласку његова јављања. Служи му са страхом као Владици по природи. Радуј му се са трепетом као цару по благодати" (Данило II 1988: 86).

Danilo stawia królową w pozycji „duchowego dziecka” Kościoła, jego poddanego i wychowanka (Jelena nazywa kler „panami”, ,ojcami”, ,nauczycielami"), którego należy troskliwie w życiu prowadzić. Nakłada na nią obowiązek przyjmowania tej kurateli z pokorą i wdzięcznością, tak jak robi to władczyni, otoczona licznymi duchowymi ojcami, prosząca kler o pomoc i radę, aby zasłużyć na przychylność Kościoła jako ziemskiego ramienia Boga dla swego panowania: „И ова блажена госпођа Јелена у сласт примаше све речи и поуке отаца ових, и красећи се, радоваше се, говорећи речи Богооца Давида, колико су слатке речи ових поука" (Данило II 1988: 86).

Rodzinne więzi, jakimi hagiograf połączył władczynię z jej religijnymi doradcami, oddają bliskie, a równocześnie złożone relacje, zależności, obowiązki i prawa między królem (państwem) a Kościołem. Relacja z biskupem Raški Pavle, którego Jelena miała uważać, według Danila, za rodzonego ojca, wydatnie wzmacnia wymowę tekstu: „За време свога живота блажена Јелена га имађаше место телеснога оца, скоро казати као господина и учитеља" (Данило II 1988: 106).

Przez osobę królowej mniszki hagiograf mocno podkreślił powagę stanu mniszego w serbskiej teokracji. Połączył królową z duchowieństwem klasztornym więzami równie silnymi, jak z parafialnym. Wybrał 
jej przewodników duchowych spośród mnichów, ich nadprzyrodzonej misji powierzył jej grzechy. Sieć rozbudowanych kontaktów władczyni z najważniejszymi monastycznymi centrami chrześcijańskiego świata Jerozolimą, Górą Athos, Synajem (monaster św. Katarzyny), monasterem Rutho/Raithu (współcześnie At-Tur, znane też jako Tur Sinai) ${ }^{13}$ - służy do podniesienia prestiżu państwa, nadania rządom Jeleny formy ponadnarodowej, uniwersalistycznej, cesarskiej:

и колико је имала духовне оце у светом граду Јерусалиму, на Синају и Раиту и у Светој Гори Атонској, јер тамо одоше многи њезини дарови (...), јер све имање тамо источивши, до смрти непрестано шиљаше часне и достоверне и великоимените монахе своје (Данило II 1988: 85).

Kościół ze swojej strony uznaje w Jelenie godnego szacunku ,zewnętrznego biskupa" ${ }^{\prime \prime}$, wybranego przez Boga i mianowanego do sprawowania urzędu aktem konsekracji. Hagiograf wyraźnie zaznacza, że zwierzchnictwo królowej nie nosi sakramentalnego charakteru, który upoważniałby ją do ingerencji w działanie Kościoła. Realizuje ona swoje powołanie w Kościele i przez Kościół, jak o tym świadczy scena święcenia olejów „rękami” duchowieństwa ${ }^{15}$. Władza króla nad Kościołem rozciąga się w zakresie opieki materialnej ${ }^{16}$ (,ktitorstwo”) i w tzw. prawie prezenty (podawania) przedstawiania władzom kościelnym wybranego przez siebie duchownego na stanowisko zwierzchnika. W Gradacu na przykład Jelena nadaje regułe monasterską (typikon), ustala zasady funkcjonowania, wybiera igumena (Данило II 1988: 94-95). W zamian Kościół wspiera ją w rządach.

Zadania królowej wobec świeckich są efektem religijnego rozumienia najwyższego politycznego urzędu w państwie. Głównym ziemskim celem

${ }^{13}$ Związki z monasterami w Palestynie i na Synaju Nemanjicie utrzymywali przez cały okres swego panowania (Амфилохије 1981).

${ }^{14}$ Konstantyn Wielki miał powiedzieć: „Sam Bóg ustanowił mnie biskupem zewnętrznym Kościoła" (Euzebiusz, De Vita Constantini, 4, 24; cyt. za Flis 2001: 279).

15 „Тако блажена Јелена чинећи, никако се не умори нити измени своју нарав добрих дела, како је навикла. Од суботе до суботе масла крстећи рукама многих јереја" (Данило II 1988: 91).

${ }^{16}$, „...) а трудила се о томе, како ће давати милостиње у божанствене храмове, и све што је на потребу, стављајући божаствене књиге у своме дому, а исто тако и свештене сасуде, златне и сребрне, украшене бисером и скупоценим камењем, изабране одежде јерејима и сваке црквене правде, што је на потребу” (Данило II 1988: 87). 
władczyni jest prowadzenie poddanych do Boga za pośrednictwem misji obronnej (ochrona przed wrogiem zewnętrznym), opiekuńczej (umacnianie i uwalnianie od kłopotów materialnych ${ }^{17}$ ), nauczycielskiej (funkcja formująca, nauczanie wiedzy praktycznej), wchodzących w ramy służby Bogu, więc także w bezpośrednią zależność od Kościoła. Nawet oświatowy patronat Jeleny, z jakiego zasłynęła w życiu, połączył Danilo z wielbieniem Boga, nawiązując do apostolskiego nakazu opieki nad sierotami (wg Jk 1,27) ${ }^{18}$.

W swojej literackiej kreacji hagiograf obdarzył królową wszystkimi atrybutami (ma „wszystkie cnoty”) potrzebnymi, by skutecznie pełnić zlecone jej posłannictwo wśród poddanych. Wyraził je symbolicznie poprzez zespół ewangelicznych cnót, błogosławieństw (według kazania na górze, Mt 5) i charyzmatów, łącznie z rzadkim u królów darem mądrości ${ }^{19}$. Ten bogaty wizerunek inspirowany jest obrazem Chrystusa Króla i Sędziego (za Mt 25,31-41) oraz figurą dziewiczej Matki Boga, pełnej łaski, nosicielki wszystkich cnót. Mając udział w królewskiej władzy Chrystusa i w majestacie Bogurodzicy, Jelena ucieleśnia archetyp matki narodu ${ }^{20}$, władczyni łagodnej i surowej jednocześnie, zarządzającej powierzoną przez Pana dziedziną w duchu odpowiedzialności przed $\mathrm{Nim}^{21}$ dla dobra poddanych (Данило II 1988: 83):

подвизава се добрим подвигом, украшавајући се сваким добрим делима, и освећујући се у сваком добром животу, уздржљвошћу изнад природе. Овака је била

17, „...) много година проведе живећи у овом веку, љубећи ниште, и дајући милостињу странима, одевајући наге, и уводећи у дом бескућнике” (Данило II 1988: 86); „и у те дане довољно милостиње дајући свакоме који је требао, насићујући гладне утробе, и одевајући наге, а болнима и странима и који нису имали где главе поклонити, беше ова блажена тврди покров и необорима кула" (Данило II 1988: 91).

18 „Заповеди у целој својој области сабирати кћери сиротих родитеља, и њих хранећи у својим дому, обучаваше сваком добром реду и ручном раду, који приличи за женски род” (Данило II 1988: 88).

${ }^{19}$ Wprowadzony do kanonu królewskich cnót przez Euzebiusza z Cezarei (263-339), biografa Konstantyna Wielkiego.

${ }^{20}$ Tworząc obraz idealnej prawosławnej władczyni i powielając średniowieczny model hagio-biografii, autor opiera się m.in. na postaci i autorytecie Stefana Nemanji (św. Simeona) - widoczna jest między nimi paralela: „święty król-ojciec” (Nemanja) - „święta królowa-matka" (Jelena). O zbieżnościach na poziomie tekstualnym w żywotach obu świętych v. Vukovich 2013: 249-266.

${ }^{21}$, ,...) он је једини Бог богова и Господ над господарима” - pisze we wstępie Danilo. I dalej: „целим својим умом [Jelena - D.G.] брине се како ће угодити Господу”. 
нарав ове блажене: оштра речју, а блага по природи, непорочна животом, у заповедању кротка (2 Sm 18,5), да обрати доброразумним речима, да теши нелицемерно (Łk $6,41-42 ; 12,1)$ и безлобно, а колика је свесрдачна њезина смелост к Богу (2 Kor 3,4-6), просто казати, била је украшена сваком врлином. Опевану и свехвалну благодат имађаше (1 Р 5), коју је примила просвећењем св. Духа, познавајучи све књиге, била је готова да отговори свакоме ко је пита (1 Kor 12,8) (Данило II 1988 : $83)$.

Mimo postawienia na pierwszym planie cnót łagodności, dobroci i miłosierdzia, stosunki między królową a poddanymi odzwierciedlają hierarchiczne relacje z Kościołem, tylko że tym razem dominującą pozycję zajmuje władczyni stojąca na straży interesów religii ${ }^{22}$ i wyznaczająca granice praw ludu. Ich przekroczenie grozi karą, ukrytą pod - na pozór niewinnie brzmiącym -,,prawem karcenia” („,оштра речју”).

Autor nie zna jeszcze pojęcia Kościoła oficjalnego, który zajmuje uprzywilejowane miejsce w państwie i cieszy się szczególnymi względami króla, ale z całą pewnością Serbia Jeleny w opracowaniu Danila nie jest teokracją ekumeniczną. Z otoczenia władczyni hagiograf wyeliminował wszystkich katolickich doradców, a opiekę nad Kościołem ograniczył do prawosławnego, nie wspominając żadnej formy wsparcia ofiarowanego zakonom katolickim (cf. Данило II 1988: 92), mimo że pod względem donacji przyjął serbską monarchinię w poczet najbardziej szczodrobliwych „nowych Helen” (cf. McClanan 1996). Popović wyjaśnia ten fakt założeniami polityczno-religijnego programu króla Milutina: „Њен православни култ је установљен у време писања житија 1317, а и једно и друго је део Милутиновог програма да да легитимитет својим наследницима после Драгутинове смрти" (Поповић 2010: 57).

Szeroko zakrojoną politykę królowej, w ramach której jednakowo traktowała ona różne wyznania, Danilo sprowadził do ewangelicznie rozumianych cnót miłości i miłosierdzia dla wszystkich bez wyjątku: własnych poddanych i obcych potrzebujących pomocy ${ }^{23}$, szczodrze ,wszyst-

${ }^{22}$ Odejście od Boga to niewybaczalny grzech, dlatego Jelena woli być niewolnicą u Pana choćby dwa dni, niż służyć innym (dosł. „diabłu i grzechowi”). Niestraszne jej żadne ziemskie prawo, boi się tylko przestąpienia Bożych przykazań (cf. Ps 119 [118]) i gniewu Bożego, bo bez Boga nawet „nie warto się rodzić”: „Мени је довољно ако и два дана будем робиња Теби Владици моме Христу (...), а да не будем робиња (бесовима) и греху. (...) јер боље би ми било да се нисам ни родила" (Данило II 1988: 91).

${ }^{23}$, „...) дајући милостињу странима” (Данило II 1988: 86). 
kim” rozdawanej jałmużny, powszechnie okazywanej pokory: „Великога и малога, богата и ништа, праведника и грешника, болна и здрава, свакога од њих једнако је поштовала и свакоме дужну част одавала". (Данило II 1988: 85).

Zasady teokratyczne zaprezentowane w tekście Danilo wskazuje jako największą wartość dla króla i kraju. Należą one do depozytu wiary przekazywanego młodym pokoleniom w procesie wychowania. Realizowanie ideału teokracji staje się obowiązkiem następców serbskiego tronu i warunkiem koniecznym istnienia państwa, jak o tym mówi autor w testamencie ideowym Jeleny przekazanym synom, od których zależy ciągłość monarchii. Pozwolę sobie zacytować dłuższy fragment żywota, ponieważ jest kluczowy dla omawianego tematu:

Децо моја љубима у Господу, (...) не одбаците поуке ваше матере, сећајте се да сте пород и васпитање хришћанске вере и народа светога и благовернога, од младости ваше вођени и крепљени Духом светим, никада не бојећи се, от противљенија иноплемених народа, који вам чине насиље, него крсним знаком ограђивани све такове победисте и низложисте, пошто је Бог због свога човекољубља утврдио ваш престо да непоколебљиво владате у своме отачаству. Зато за сва добра која вам учинио, дужни сте да му служите (...). Прародитељи ваши изнеше пред Бога добра дела и подвиге, држећи земаљско царство, и у нему богоугодно живећи, управљајући смислено и разумно своим имањем, делећи дарове божаственим црквама, милостињу ништима и странима, и тако чинећи, нађоше себи Господа милостива (...) а њихове молитве од Бога примљене утврђују ваше домове. Достојно је да и ви ревнујете њихову животу, да се и ви не лишите вечних добара у животу. (...) А синови блажене госпође Јелене у сласт и са страхом примаху речи и поуке своје блажене матере Јелене, повинујући јој се са сваком радошћу и истинитом побожношћу (Данило II 1988: 89).

Kult św. Jeleny nabiera współcześnie znaczenia, jest też aktywizowany poza granicami Serbii, ale kreowany obraz królowej tylko częściowo bazuje na wizerunku ukształtowanym przez Danila II. Autorzy wolą sięgać po bardziej uniwersalny dla świętości kobiet model wiązany ze św. Heleną, matką Konstantyna Wielkiego, szczodrą opiekunką Kościoła. W rezultacie idea teokratyczna również przyjmuje w nich odmienną postać i najczęściej zredukowana jest do mało rozbudowanego obrazu władczyni jako troskliwej ,ktitorki”. 


\section{Literatura}

Farlati D., 1813, Illyricum sacrum VII, Venetiis.

Flis A., 2001, Chrześcijaństwo i Europa. Studia z dziejów cywilizacji Zachodu, Kraków.

Gil D., 2005, Prawostawie. Historia. Naród. Miejsce kultury duchowej w serbskiej tradycji i współczesności, Kraków.

Hafner S., 1976, Danilo II. und sein Schüler: Die Königsbiographien, Graz.

McClanan A.L., 1996, The Empress Theodora and the Tradition of Women's Patronage in the Early Byzantine Empire. The Cultural Patronage of Medieval Women, Athens-London.

McDaniel G.L., 1982-1983, On Hungarian-Serbian Relations in the Thirteenth Century: John Angelos and Queen Jelena, „Ungarn-Jahrbuch” vol. 12, s. 43-50.

Meyendorff J., 1984, Teologia bizantyjska, Warszawa.

Naumow A., 2008, Współczesna hymnografka między tradycją a wyzwaniami świata, w: Nel mondo degli Slavi. Incontri e dialoghi tra culture, Studi in onore di Giovanna Brogi Bercoff, red. M. Salvo, G. Moracci, G. Siedina, vol. II, Firenze, s. 391-403.

Salamon M., 2002, Bela III, Aleksy, w: Encyklopedia kultury bizantyńskiej, red. O. Jurewicz, Warszawa.

Vukovich A., 2013, Motherhood as Authority in the 'Life of Queen Helen' by Archbishop Daniel II, w: Authorities in the Middle Ages Influence, Legitimacy, and Power in Medieval Society, eds S. Kangas, M. Korpiola, T. Ainonen, „Fundamentals of Medieval and Early Modern Culture" no. 12, s. 249-266.

Амфилохије (Радовић), 1981, Синаити и юихов значај у животу Србије XIV и XV века. Споменица о шестој стогодишњици манастира Раванице, Београд.

Васић М., 1926, Архиепископ Данило II, „Прилози за КЈИФ” VI, s. 240-355.

Данило II, 1988, Житије краљице Јелене, w: Животи краљева и архиепископа српских. Службе, ур. Г. Мак Данијел, Д. Петровић, прев. Л. Мирковић, Београд, s. 79-108.

Злоковић М., 1936, Градачка ирква, задужбина краљище Јелене, „Гласник Скопског научног друштва” XV-XVI, s. 61-80.

Јиречек К., 1952, Историја Срба, II, Београд.

Мијатовић Ч., 1902, Ко је краљица Јелена?, „Летопис Матице Српске” 217, Нови Сад.

Митић М., 1997, Свето писмо у Житију краљице Јелене од архиепископа Данила II, w: Српска књижевност и Свето писмо, 26. научни састанак слависта у Вукове дане, Београд, Манасија, 9-14.9. [1996.], ур. Ј. Ређеп и др., Београд, s. $61-70$.

Наумов А., 2013, Службата на преподобната Филотея Темнишка като отражение на православната духовност през ХIII век, w: In Honотет ТРІАNTAФҮАЯО. Юбилеен сборник в чест на 60-годишнината на проф. д.фил.н. Христо Трендафилов, ред. В. Панайотов, Шумен, s. 426-432. 
Павловић Л., 1965, Култови лица код Срба и Македонаияа, Смедерево.

Поповић J., 1998, Житија светих, Ваљево, wersja on-line: <www.svetosavlje.org/ biblioteka/avajustin/zitijasvetih/Lat_ZitijaSvetih10.htm>, 22.09.2014.

Поповић М., 2010, Српска краљиияа Јелена између римокатоличанства и православља, Београд.

Суботић Г., 1958, Краљииа Јелена Анжујска - ктитор црквених споменика у Приморjy, „Историјски гласник” nr 1-2, s. 131-147.

Ћирковић С., 1981, Историја Српског Народа I, Београд.

Ћоровић В., 1997, Историја Срба, Београд, <www.rastko.rs/rastko-bl/istorija/corovic/istorija/3_4_1.html>, 5.02.2016.

Филарет (Гумилевский), 1865, Святые южных славянъ: Опыт описания жизни $u x$, т. 1-2, Чернигов.

Шекуларац Б., 1984, Врањинске повеље, XIII-XV вијек, Титоград. 